\title{
Anabases
}

ANABASES Traditions et réceptions de l'Antiquité

9 | 2009

Varia

\section{Antiquité et psychologie des ruines}

\section{Catharine Edwards}

\section{(2) OpenEdition}

\section{Journals}

Electronic version

URL: http://journals.openedition.org/anabases/520

DOI: 10.4000/anabases.520

ISSN: 2256-9421

\section{Publisher}

E.R.A.S.M.E.

\section{Printed version}

Date of publication: 1 March 2009

Number of pages: $267-270$

ISSN: 1774-4296

\section{Electronic reference}

Catharine Edwards, «Antiquité et psychologie des ruines », Anabases [Online], 9 | 2009, Online since 01 March 2012, connection on 21 October 2019. URL : http://journals.openedition.org/anabases/520 ; DOI : 10.4000/anabases.520 
Anabases 9 (2009), p. 267-270.

\section{Antiquité et psychologie des ruines}

Catharine Edwards

ANTIQUITY AND THE RUIN: vision, time, emotion, fragmentarity and the reception of the past. An international conference, June $5^{\text {th }}-7^{\text {th }}$ 2008, University of London, Institute in Paris.

For the sociologist Georg Simmel (in his 1911 essay "Die Ruine"), ruins embody a tension between culture and nature; the human process of construction is balanced by the natural process of ruination, generating a new whole, one which allows those who experience ruins aesthetically to overcome their sense of alienation from modern life. All too often, though, ruins have been testimony rather to human forces of destruction. Two papers, in this rich and wide-ranging conference on antiquity and the ruin (beautifully organised by Ahuvia Kahane and Anastasia Serghidou), invited us to think about the ruins of Berlin and Munich in the aftermath of World War II. Andreas Wittenburg, in his discussion of ruins as a reminder of the crimes of the past, drew a suggestive parallel between the decision to leave as ruins those buildings of the Ionian Greeks destroyed by the Persians (a circumstance related by Isocrates and Cicero) and the preservation of the ruins of the Kaiser Wilhelm Gedachtnis Kirche in Berlin and the Königsplatz in Munich as testaments both to the final overthrow of the Nazi regime and also to the destructiveness of war. Rüdiger Zill, too, explored the significance of these ruins in their role as allegories, here as a point of comparison with a romantic perspective on the natural world, which could itself be viewed as a ruin, testimony to the devastating forces of the deluge. The discussion following these papers also explored the degree to which these more recent ruinprocesses, which have so profoundly shaped our world, have also coloured our own engagement with the ruins of antiquity.

The specificity of our engagement with ruins was a constant concern of the papers and discussion. The conference opened with a suggestive and thought-provoking presentation by Salvatore Settis, which charted shifting views of ancient ruins, particularly those of the city of Rome, since the renaissance. Rome's ruins are framed, given meaning, by the fall of Rome and later by the sack of Rome. Settis argued for the distinctively western nature of the preoccupation with contemplating and preserving ruins, drawing a striking contrast with the relative lack of 
interest in the ruined nature of ancient structures in Chinese culture. Alain Schnapp's subtle and erudite discussion of ruins as antiquities (informed by Jan Assmann's important work on culture and memory) also drew on cross-cultural comparisons, in this case with Mesopotamia as well as China, highlighting some of the earliest known instances of ancient remains preserved as monuments of the past.

Jean-Pierre Vallat's fascinating presentation "Heritage, memory, identity", examining Unesco's listing of world heritage sites in different countries and regions (a listing in which some parts of the world have a far higher profile than others), raised some crucial questions about the specificity of notions of ruins as heritage. The particular choice of sites for Algeria, for instance, reflects a certain conception of its identity in term of medieval urbanism. Yet as the subsequent discussion emphasised, even within Europe "patrimoine", "patrimonio" and "heritage" are terms which themselves have a particular and distinct history; they cannot be straightforwardly equated. Mary Beard's presentation offered a subversive emphasis on the disappointment ruins can often generate. Why should we suppose that ruins offer the most vivid form of contact with antiquity? Is this assumption anything more than the product of cultural snobbery, a strategy to exclude those who struggle to decipher the mess of ruins? Are reconstructions necessarily inferior? The notion of authenticity implicit in celebrations of ruins is by no means universal.

My own paper "Personalising ruins" looked at the responses to the ruins of Rome in women's writing of the nineteenth century. How far was Rome perceived as the patrimony of the educated European male, to the exclusion of others? Mme de Stäl's erudite heroine Corinne sees the ruins of Rome as a spur to political change but also a catalyst for romantic engagement. Yet love among the ruins cannot have a happy outcome even for its most learned female devotee. Decades later George Eliot's Dorothea Brooke looks for both learning and love on her Roman honeymoon but is merely overwhelmed by the incomprehensible fragments of a violent imperial past. As was pointed out in the subsequent discussion, however, many female visitors found Pompeii a much more accessible point of entry to Roman antiquity. Here, in contrast to Rome, one needed no complex apprehension of Roman history but might respond much more immediately to the domestic detail of its material remains.

Edith Hall's impassioned paper speculated on Karl Marx's response to the Roman ruins of Trier, the city of his birth, ruins which were only a few feet from the house in which he grew up. Ruins recur suggestively in a number of Marx's early works (including his $\mathrm{PhD}$ thesis on Lucretius), while the institutions of the Roman empire form a key point of reference in some of his most important work (Hall suggestively explored Marx's interest in ancient patterns of land-holding, in relation to those of his own time in the once Roman occupied area of his own birth and youth).

Even in antiquity, ruins could be the occasion for melancholy reflection. Cicero's correspondent Sulpicius offers his own response to the ruins of Aegina and Corinth, cities once so flourishing, as a source of consolation to Cicero, devastated by the loss of his beloved daughter Tullia (a shift from the general to the particular which was perhaps of limited efficacy in that context). Moving on from such earlier invocations of ruins, Philippe Bourgeaud's rich paper "Regret, survival or superstition: some reflections on the ruins of polytheism and the tears of the last pagans" explored the complex combination of regret and nostalgia in responses to the remains of pagan temples in late antiquity. The semantics of ruins in antiquity, here particularly in the Greek world, formed the subject of Anastasia Serghidou's erudite and wide-ranging paper, which explored different strategies for the location of the "ereipion" in time, as well as the central 
role of melancholy in responses to ruins. François de Polignac offered an elegant and subtle discussion of ancient and medieval engagements with material reminders of Alexander the Great in Egypt and elsewhere; ruins remind the observer of a lost heroic age.

Richard Alston's paper "Caesar in ruins: memory and resistance" also focused on ancient engagements with ruins, exploring Tacitus' account (in the Annals) of Germanicus viewing antiquities at Athens and at Troy, as well as in Egypt. These fallen cities become portents of Germanicus' own personal downfall but also of the future of Rome itself. Lucan's Julius Caesar at the site of Troy fails to decipher the ruins before him, both literally (trampling on the tomb of Hector) and metaphorically (if Rome is founded on the ruins of Troy, will not Rome, too, turn to ruin?). Might such ruin narratives, Alston asked, themselves work to justify the existence of the imperial state, the only means to keep the spectre of ruination at bay?

James Porter's discussion "Sublime monuments and sublime ruins in ancient aesthetics" also focused on antiquity, in particular on the role of ancient monuments as an expression of loss and permanence in a heightened form of tension, a tension which serves to generate sublimity, in the sense articulated by Longinus. Indeed, developing Jesper Svenbro's exploration of la parole et le marbre, Porter traces the same effect in texts which serve as metaphorical monuments, particularly Hellenistic epigrams and the literary critical movement of euphony.

Metaphorical ruins were the subject of Pietro Pucci's subtle and thought-provoking paper on fragments, which, following Derrida, explored the fragmentary nature of all writing. This fragmentarity is especially highlighted in, for instance, Schlegel's experiments with writing fragments as fragments. Page duBois's paper, too, entitled "Tithonus and the ruin of the body"' focused on texts, particularly fragmentary texts. What is at stake, she asked, in responding to a piece of writing which appears to be mutilated? How far is this parallel to the response to a broken statue, such as the Venus de Milo, which may well involve looking away from its incompleteness, to see it as an object of desire? Such desire may indeed be all the more poignant. Fragments allow much greater space, she suggested, for scholars to become poets in amending the surviving text, in combining, on occasion, two fragmentary texts to form a new whole. At the same time, the broken/ruined nature of the remains of antiquity, whether material or textual, often functions as a source of pathos, especially when we choose to see ourselves reflected in these broken things.

The film Man on a wire (2008, produced by Philip Marsh) explores the obsession of one man, the tight-rope walker Philippe Petit, with walking on a wire suspended between the twin towers of the World Trade Centre, his ambition conceived, he recalls in an interview, before the towers were even completed. This mesmerising film documents the extraordinary fulfilment of his ambition in 1974, including heart-stopping documentary footage of his acrobatics, poised hundreds of metres up in the air, a hair's breadth from death. Never referred to in the film but always present in the mind of every viewer, adding a moving resonance to the film's celebration of fragile human ambition, is the destruction 27 years later of the towers, their ruin, in which so many did fall to their deaths.

The twin towers featured in Ahuvia Kahane's paper on the phenomenology of ruins, at the conclusion of the conference. He invited us to think about the tower as a symbol of human ambition, a hybristic aspiration to eternity, in which ruin is always already inscribed. While some might argue that the ruin only comes to have a place in historical consciousness from the renaissance, Kahane proposed that the image of ruined towers lay at the heart of antiquity's own historical consciousness. For all those who read or listened to the Iliad (and of course all the 
literature which succeeded that poem) Troy was always already a ruin-and indeed has actually become a ruin even in the opening lines of the Odyssey. Troy, moreover, that Ur-ruin, is ruined, we might remember, by man rather than nature.

Rome, too, we might add, appears in the Aeneid, if not before, as founded on ruins, both the metaphorical ruins of Troy, and also the material ruins of the settlements of Janus and Saturn (whose broken walls are pointed out to Aeneas by Evander in the tour of the future site of Rome in book VIII). Turning to ruin is also a return to ruin, as Poggio Bracciolini in his fifteenth-century treatise on the vagaries of fortune seems to recognise in his echoes of Virgil, and as Edward Gibbon, who himself quotes Poggio's musings on the Capitol in the opening of the final chapter of the Decline and fall of the Roman empire, was very well aware. Ruins already feature in the foundation documents of classical antiquity. It is partly for this reason, perhaps, that they have continued to play such a central role in later western engagements with the classical world.

Catharine EDWARDS

Birkbeck, University of London

Malet Street

London WC1E 7 HX

c.edwards@history.bbk.ac.uk 